Acta Technologica Agriculturae 2

Nitra, Slovaca Universitas Agriculturae Nitriae, 2018, pp. 87-93

\title{
THE POSSIBILITY OF INCREASING THE WEARING RESISTANCE OF MULCHER TOOLS
}

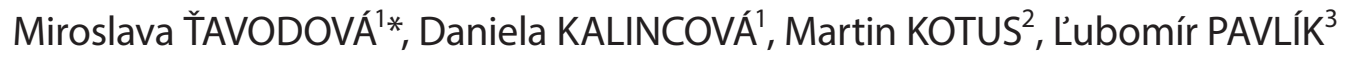 \\ ${ }^{1}$ Technical University in Zvolen, Slovak Republic \\ ${ }^{2}$ Slovak University of Agriculture in Nitra, Slovak Republic \\ ${ }^{3}$ Department of Materials and Mechanics of Machines SAS, detached workplace Žiar nad Hronom, \\ Ladomerská Vieska, Slovak Republic
}

\begin{abstract}
This paper presents a utilization of mulcher tools, their wear and possibilities of increasing their lifetime and durability based on analysis and tests. Mulcher tools are subjected to a very strong wear causing the loss of soldered WC tips in some cases and even permanent deformation of the body tool made of steel 14220 (16 MnCr5) during the continuous use. Images depicting the loss of material from the mulcher tool due to wear were produced by overlaying the pre- and after-wear tools by means of the optical scanning system. Input analyses - measuring of hardness, impact test and evaluating of microstructure showed that forging is without heat treatment. This does not provide sufficient mechanical properties to tools that would ensure work continuation after losing WC tips. Therefore, an appropriate process of heat treatment of the tool body has been proposed. By comparing the loss of material using abrasive test, it was observed that the wear of heat-treated material was three times lower than of material without heat treatment. This gives the precondition for increasing the resistance of the tool body and thus increasing of lifetime and durability after loss of WC tips. The implementation of such a solution could bring not only technical but also economic benefits.
\end{abstract}

Keywords: mulcher tools; microstructure; wearing; heat treatment; lifetime and durability of tools

Functional parts of the forest machinery - tools for cultivation of forest undergrowth utilized in a heterogeneous environment - are significantly subjected to abrasive wear. Due to this wear, some tools are temporarily inoperable and cause a kinetic degradation of the entire machine mechanism. The extent of wear grows linearly with the time of operation. Currently, tools from different producers (marks AHWI, SEPPI, KingKong-Tools, etc.) are utilized for mulching, milling, and crushing of unwanted growths. Although the shape of these tools is different, the material from which they are produced has to satisfy the same requirements; in majority of cases, such a requirement is high hardness ensuring abrasion resistance, as well as sufficient toughness, resistance to brittle fracture during cyclic loading and abrasive heterogeneous environment in which they are utilized (Tolnai et al., 2006; Votava et al., 2005). Their lifetime, which has to be at such a quality level as to meet the economic criteria, depends on these properties. Possibilities of increasing the lifetime of tools lie mainly in caring for enormously loaded functional areas, which are the very first parts liable to deformation after losing the soldered tips. It is provided that by utilization of appropriate procedures - e.g. heat treatment for changing the microstructure and, hence, increasing their wear resistance - will result in prolongation of their lifetime (Kalincová and Ťavodová, 2016).

\section{Material and methods}

Mulching is a mechanized type of work during which the above-ground parts of vegetation are being destroyed and crushed. In silvicultural and agricultural terminology, mulching represents a method of soil protection by decomposition of the mulched mass. Mulch is a layer of organic mass that is spread on the surface of soil in order to improve the soil environment for plant growing. The term mulching covers different kinds of technological processes which are used mainly in agriculture, forestry and maintenance of public green spaces, etc. (Hnilicová et al., 2016; L'uptáčiková, 2016). In forestry, different constructional variants of crushing devices are used as adapters of the wheeled forestry tractor for skidding. They are of specific construction, most frequently there is a rotating cylinder with a speed of $n=1,000 \mathrm{rpm}$ attached to a base of machine, on the periphery of which there are working tools of various shapes and designs (Fig. 1).Very often, these systems are also used for maintenance of areas under high voltage. These areas are in an inaccessible terrain that requires reliable and agile machines (Hnilica et al., 2015).

Tools themselves are either produced with monolithic or composite structure - a tool body with spiked carbide tips, respectively, hard-tipped tips. 

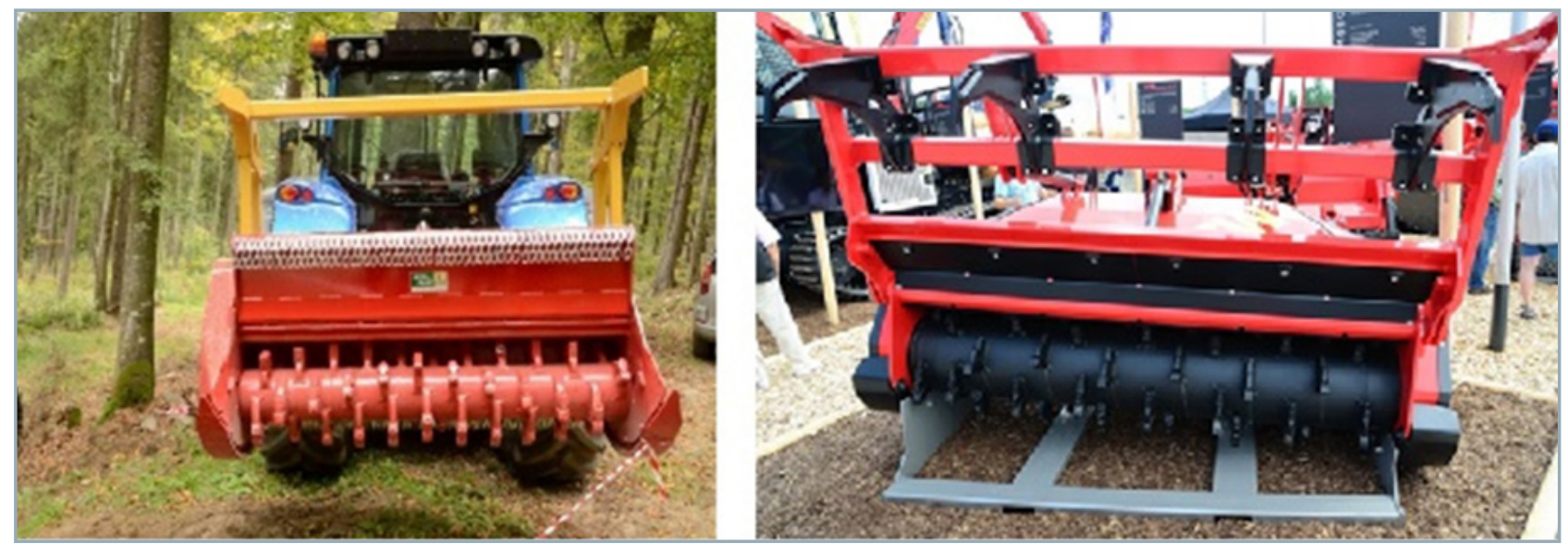

Fig. 1 Examples of types of adapters for crushing of unwanted growths

Source: Forestry Mulchers, 2017

The tools of a mulcher, shredder or soil milling machine are abrasively worn in a heterogeneous environment. Abrasive wear is characterized by separation of material particles from the functional surface due to contact with a harder and rougher surface of another body or by action of abrasive particles. Depending on the nature of mutual interactions in abrasive wear, two basic models are distinguished. The first is the wear in the reaction of two bodies, the most frequently of the particles and the functional surface. A typical example is the wear of parts in soil processing, raw material extraction, etc. (Buckley, 1981; Blaškovič et al., 1990).

Until now, there is no uniform opinion on the most appropriate type of material structure in terms of resistance to abrasive wear. Some authors consider austenitic-carbide to be a suitable structure, others martensitic-carbide structure. These different views stem from the diversity of the abrasive wear process and wide range of operational conditions (Müller and Hrabě, 2013; Krauze et al., 2015).

Each structural component has its share in the overall level of resistance of metal during the exploitation process. In relation to abrasive wear, two critical stages have to be distinguished: the injection process of an abrasive to the surface in which the limiting factor is hardness; and the surface deterioration process in which the limiting factors are the strength of the interatomic bond, as well as the strength of the connection between the structural components at the boundaries of the grains (Ťavodová et al., 2016).
Tool wear, mainly due to abrasion, has a direct impact on the total time of discontinuities (disturbances, replacement of worn parts, etc.) in operation and the quality of work done. One of the reasons for significant wear of soil treatment tools are hard particles of $\mathrm{SiO}_{2}$ with hardness ranging from 900 to 1280 HV (Votava, 2014).

The wear resistance of a specific material depends also on its microstructure in addition to other factors. Therefore, it is impossible to presume its wear resistance with guarantee (Brožek and Nováková, 2008).

There are several possibilities of increasing the wear resistance of tools:

- soldering of wolfram-carbide tips on the tool body currently the most utilized method;

- application of welds to the exposed parts of the tool body while retaining soldered tips;

- surface heat treatment of the tool material in the exposed parts of the tool body in order to provide a more wearresistant structure;

- application of welds to destroyed tools (loss of toe wolfram-carbide tips) - renovation of tools;

- complete change of tool material - e.g. HARDOX steel.

\section{Experiment}

Analysed tool used for mulching is made of steel 14220 , DIN-16MnCr5, designation - chromium-manganese steel for cementation. In regards its composition, this material

Table 1 Chemical composition of steel $16 \mathrm{MnCr} 5$ (according to standard)

\begin{tabular}{|c|c|c|c|c|c|}
\hline \multicolumn{7}{|c|}{ Chemical composition (weight \%) } \\
\hline C & Mn & Si & Cr & P & S \\
\hline \hline $0.14-0.19$ & $1.10-1.40$ & $0.17-0.37$ & $0.80-1.10$ & max. 0.035 & max. 0.035 \\
\hline
\end{tabular}

Table 2 hemical composition of tool material - steel $16 \mathrm{MnCr} 5$ detected by spectral analysis

\begin{tabular}{|c|c|c|c|c|c|c|c|}
\hline \multicolumn{7}{|c|}{ Chemical composition (weight \%) } \\
\hline C & Mn & Si & Cr & Mo & Ni & Co & Fe \\
\hline 0.195 & 1.199 & 0.219 & 1.150 & 0.046 & 0.103 & 0.011 & 96.9 \\
\hline
\end{tabular}




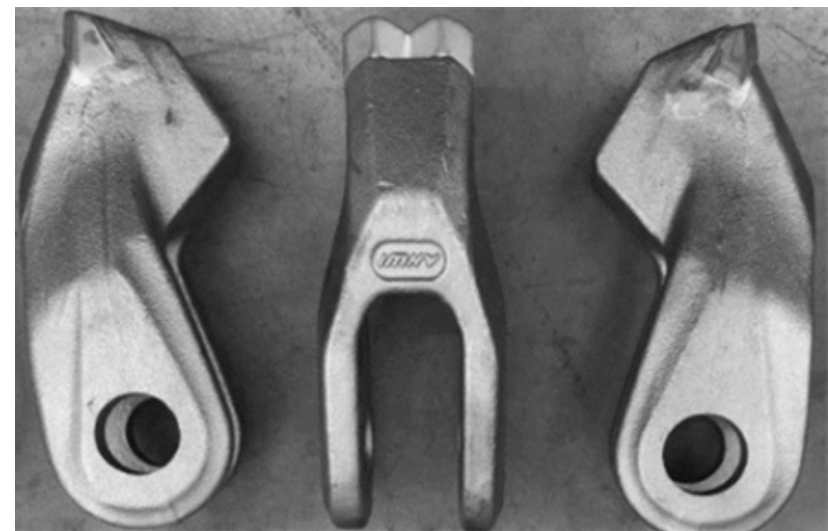

Fig. 2 Mulching tool-new Source: authors

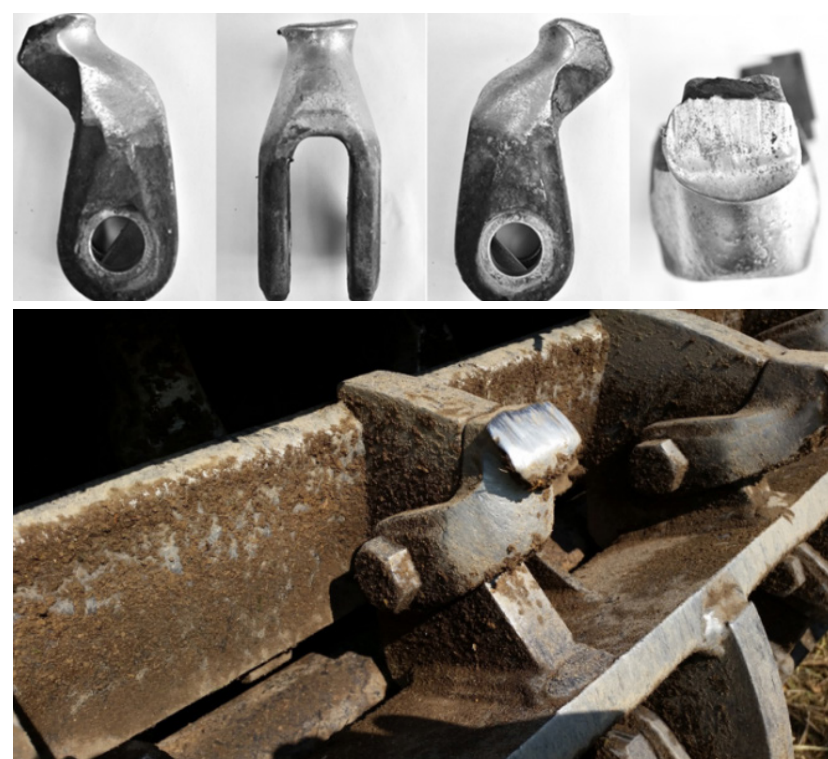

Fig. 3 Worn mulching tool - worn mulching tool on the LKT adapters Source: authors

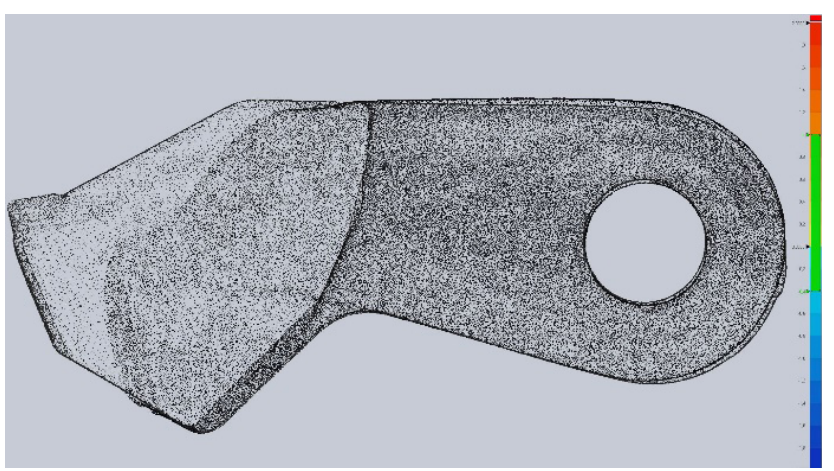

Fig. 4 Loss of material of the mulching tool Source: authors can be considered tool steel 19 486. It belongs to a group of low carbon steels, which have good plastic properties even after quenching without hardening (Ťavodová et al., 2016). The chemical composition of the steel according to the material sheet is given in Table 1.

To confirm the content and presence of chemical elements in steel, we performed a spectral analysis; the results are shown in Table 2 .

The results of analysis almost completely correspond with the composition given by STN 41 4220. It is possible to claim that the content of elements in steel which do not comply with the given tolerance will not influence the test results.

\section{Macro- and microscopic analysis of the tool}

According to the manufacturer (www.kingkong-tools. com), the tool body is made by means of thermoforming technology such as forging. It is equipped with tungstencarbide tips that are coupled with hard Ag solder (Fig. 2).

Fig. 3 shows the images of a worn tool. In operation, it is subjected to impacts and abrasive wear, resulting in visible deformation of the tool body after loss of tips and worn tool on the rotating cylinder of the skidding forestry tractor adapter.

An optical scanning system with a laser projector and two 2MP PointGrey cameras was used for scanning of a new and worn tool in FlexScan3D from 3D LMI. Measurements were processed by software Geomagic Verify by Geomagic. Overall evaluation was carried out at INOVAL - the Institute of Materials and Mechanics of SAV machines, the detached workplace in Žiar nad Hronom. Overlapping of both tools resulted in an image showing the loss of material of the mulching tool after approximately 80 hours of work in terrain (Fig. 4).

By microscopic analysis, we evaluated the microstructure of the tool shown in Fig. 5. Microstructure was ferritic-pearlite with indications of recrystallization in several parts of grains. The structure was without heat treatment in original state.

In order to obtain a microstructure with a higher hardness (without free ferrite), construction of the tool included quenching and tempering before soldering the hard metal tips. The heat treatment mode was selected in accordance with the steel standard $16 \mathrm{MnCr} 5$ (Table 3). We

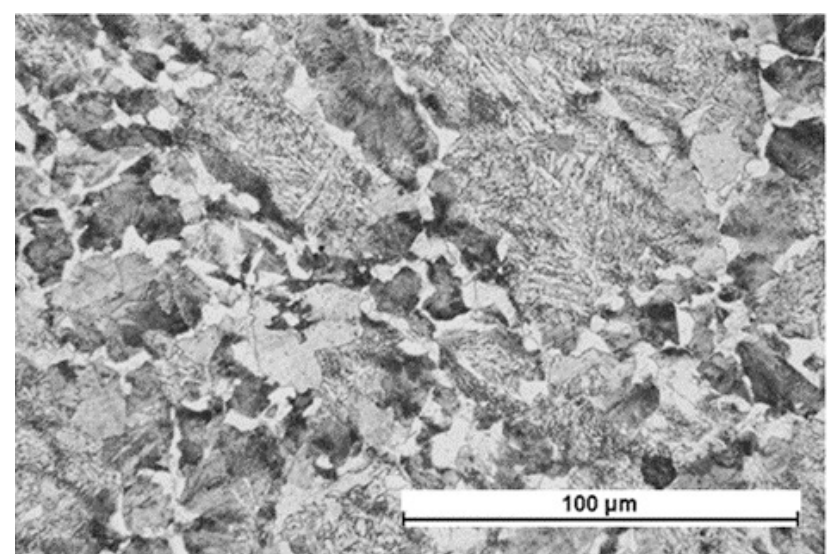

Fig. 5 Microstructure of tool material before heat treatment, $2 \%$ Nital

Source: authors 
assume that the finer structure obtained by quenching and tempering provides better properties, especially higher hardness, which increases resistance to abrasive wear.

For quenching, the heating temperature of $820{ }^{\circ} \mathrm{C}$, lasting for 40 minutes, and cooling in oil were selected. For tempering, the heating temperature of $500{ }^{\circ} \mathrm{C}$, with subsequent cooling in air and duration of 20 minutes, was

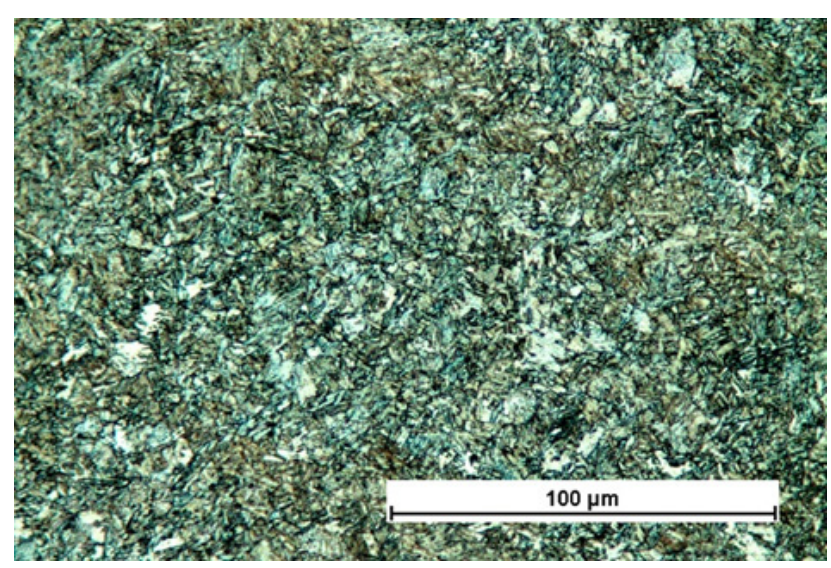

Fig. 6 Microstructure of the material after the heat treatment, $2 \%$ Nital

Source: authors selected. Fig. 6 shows the structure of the tool material after heat treatment. By quenching and subsequent tempering, we have achieved a finer structure consisting of tempered martensite and fine grain carbide, with little identifiable residual austenite.

\section{Hardness measurement}

We used the Brinell and Rockwell method to determine the hardness of the tool material before heat treatment. The values of Brinell and Rockwell hardness are listed in standard of material $16 \mathrm{MnCr} 5$. The Values of $\mathrm{HB}$ hardness after heat treatment are $208-269 \mathrm{HB}$. The measured values are shown in Table 4.

Measuring of HRC hardness was performed for comparison whether heat treatment increases the hardness of materials. The measured values are shown in Table 5 .

The material hardness values correspond to the values given in the material standard $16 \mathrm{MnCr} 5$. After quenching, we measured the hardness again using Rockwell's hardness meter; the measured values are shown in Table 6.

Vickers hardness test was performed in accordance with STN ISO 6507-1 (2006). The measured values are given in Table 7 and Table 8 . The values of hardness were proven to be higher after heat treatment.

Table 3 Parameters of heat treatment of steel $16 \mathrm{MnCr} 5$

\begin{tabular}{|l||c|c|c|c|}
\hline \multirow{2}{*}{ Material } & \multicolumn{2}{c|}{ Quenching } & \multicolumn{2}{c|}{ Tempering } \\
\cline { 2 - 5 } & temperature $\left({ }^{\circ} \mathrm{C}\right)$ & medium & temperature $\left({ }^{\circ} \mathrm{C}\right)$ & medium \\
\hline Steel 16MnCr5 & $800-840$ & oil & $450-500$ & air \\
\hline
\end{tabular}

Table 4 Hardness values HB 30 before heat treatment

\begin{tabular}{|l||c|c|c|c|}
\hline Indentations & $\mathbf{1}$ & $\mathbf{2}$ & $\mathbf{3}$ & Average value \\
\hline Value HB & 229 & 285 & 255 & 256 \\
\hline
\end{tabular}

Table 5 Hardness values HRC before heat treatment

\begin{tabular}{|l||c|c|c|c|}
\hline Indentations & $\mathbf{1}$ & $\mathbf{2}$ & $\mathbf{3}$ & Average value \\
\hline Value HRC & 21 & 22 & 17 & 20 \\
\hline
\end{tabular}

Table 6 Hardness values HRC after heat treatment

\begin{tabular}{|l||c|c|c|c|}
\hline Indentations & $\mathbf{1}$ & $\mathbf{2}$ & $\mathbf{3}$ & Average value \\
\hline Value HRC & 35 & 34 & 36.5 & 35 \\
\hline
\end{tabular}

Table 7 Hardness values HV10 before heat treatment

\begin{tabular}{|l||c|c|c|c|}
\hline Indentations & $\mathbf{1}$ & $\mathbf{2}$ & $\mathbf{3}$ & Average value \\
\hline \hline Value HV10 & 281 & 229 & 238 & 225 \\
\hline
\end{tabular}

Table 8 Hardness values HV10 after heat treatment

\begin{tabular}{|l||c|c|c|c|}
\hline Indentations & $\mathbf{1}$ & $\mathbf{2}$ & $\mathbf{3}$ & Average value \\
\hline Value HV10 & 350 & 341 & 338 & 343 \\
\hline
\end{tabular}




\section{Charpy pendulum impact test}

In order to determine whether the material after quenching is suitable for such load as the tool tends to be exposed to, we have tested the toughness on Charpy's hammer according to STN EN ISO 148-1:2017. On the prepared three samples, heat-treated and non-heat-treated, a hammer-bending test with a nominal work of $300 \pm 10 \mathrm{~J}$ was performed. Table 9 shows the values of toughness and impact stress.

The standard STN 414220 lists the notch toughness values $49 \mathrm{~J} . \mathrm{cm}^{-2}$. Samples after heat treatment show higher toughness than samples without it. This guarantees higher wear resistance of tool body.

\section{Measurement of wear resistance of materials}

The standard STN 015084 was used for evaluation of the resistance of abrasion-resistant material. Although this standard is currently not valid in Slovakia and lacks substitution, it is still valid in the Czech Republic under designation ČSN 01 5084. The evaluation of material resistance to abrasive wear was carried out at a test facility in the laboratory of the Department of Quality and Engineering Technologies of the Faculty of Engineering, SUA in Nitra. Fig. 7 depicts the apparatus with a basic scheme.

The instrument and test parameters for the tests are shown in Table 10.

Test specimens were produced in accordance with the ČSN 015084 standard from the mulcher tool material. The four samples were made of material without hear treatment (Fig. 8a) and four samples with heat treatment (Fig. 8b).

The values describing sample weights before and after the wear resistance test as well as weight differences are
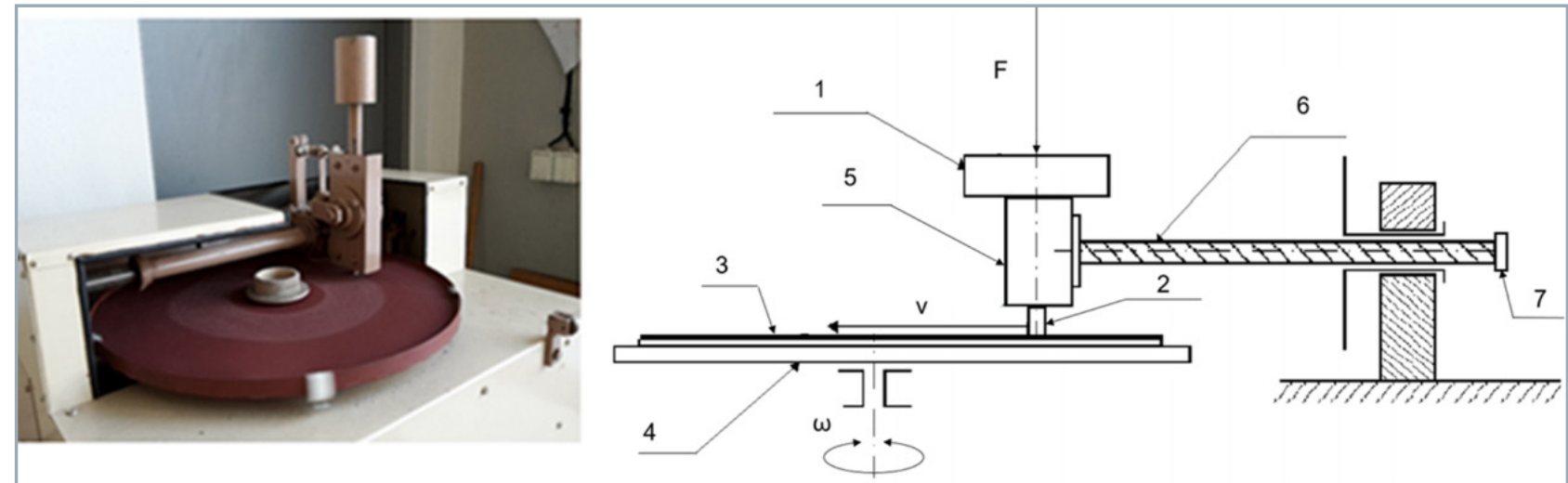

Fig. 7 Testing device for abrasion resistance test with basic scheme

1 - weight; 2 - sample; 3 - abrasive cloth; 4 - rotating disc; 5 - clamping head; 6 - motion screw; 7 - limit swith Source: authors

Table 9 Impact stress and notch toughness values

\begin{tabular}{|l||c|c|c|c|}
\hline Sample & Non-heat-treated KV $(\mathbf{J})$ & Heat-treated KV $(\mathbf{J})$ & Non-heat-treated KCV $\left(\mathbf{J} . \mathbf{c m}^{-2}\right)$ & Heat-treated KCV $\left(\mathbf{J} . \mathrm{cm}^{-2}\right)$ \\
\hline $\mathbf{1}$ & 18 & 50 & 22.5 & 62.5 \\
\hline $\mathbf{2}$ & 18 & 55 & 22.5 & 68.75 \\
\hline $\mathbf{3}$ & 14 & 55 & 17.5 & 68.75 \\
\hline Average & 16.6 & 57 & 20.8 & 66.6 \\
\hline
\end{tabular}

Table 10 Device parameters and samples for wear resistance test

\begin{tabular}{|c|c|c|}
\hline \multicolumn{2}{|r|}{ Parameters of device } & \multirow{2}{*}{$\begin{array}{c}\text { Value } \\
R=50 \mathrm{~m}\end{array}$} \\
\hline 1 & Length of friction track & \\
\hline 2 & Diameter of the rotating plate & $D=480 \mathrm{~mm}$ \\
\hline 3 & Maximum friction rate of the sample & $W=0.5 \mathrm{~m} . \mathrm{s}^{-1}$ \\
\hline 4 & Holding-down pressure of the sample & $P=0.32$ N.mm $\mathrm{mm}^{-2}$ \\
\hline 5 & Radial feed per revolution of the sample & $3 \mathrm{~mm}$ \\
\hline 6 & Abrasive cloth & GLOBUS 120 \\
\hline \multicolumn{3}{|c|}{ Parameters of the test specimen } \\
\hline 1 & Sample diameter & $d=10_{0.03}^{0.01} \mathrm{~mm}$ \\
\hline 2 & Sample length & $65 \mathrm{~mm}$ \\
\hline
\end{tabular}


Table 11 Measured values - non-heat-treated samples

\begin{tabular}{|l||c|c|c|c|}
\hline & Weight before test $\mathbf{( g )}$ & Weight after test $\mathbf{( g )}$ & Weight difference (g) & Mean weight loss value (g) \\
\hline $\mathbf{1}$ & 36.9799 & 36.6713 & 0.3086 & \\
\cline { 1 - 2 } & 40.0685 & 39.7815 & 0.2870 & \multirow{2}{*}{$x=0.2994$} \\
\hline $\mathbf{3}$ & 38.2851 & 37.9895 & 0.2956 & \\
\hline $\mathbf{4}$ & 35.4317 & 35.1253 & 0.3064 & \\
\hline
\end{tabular}

Table 12 Measured values - heat-treated samples

\begin{tabular}{|l||c|c|c|c|}
\hline & Weight before test $\mathbf{( g )}$ & Weight after test $\mathbf{( g )}$ & Weight difference (g) & Mean weight loss value (g) \\
\hline \hline $\mathbf{1}$ & 38.6102 & 38.3189 & 0.2913 & \\
& 37.2864 & 36.9979 & 0.2885 & \multirow{2}{*}{$x=0.2916$} \\
\hline $\mathbf{3}$ & 37.4862 & 37.1873 & 0.2989 & \\
\hline $\mathbf{4}$ & 38.9837 & 38.6960 & 0.2877 & \\
\hline
\end{tabular}

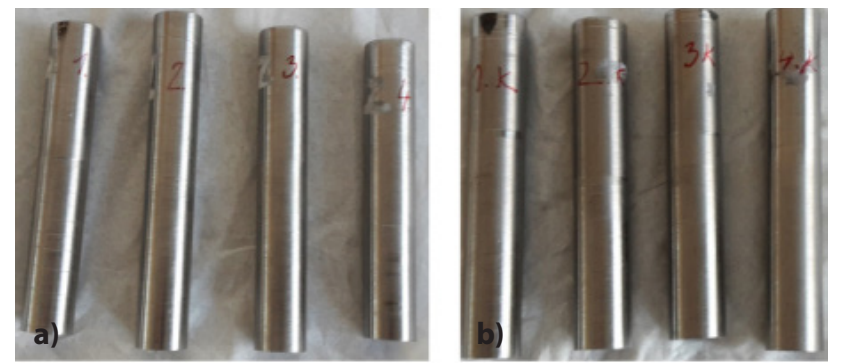

Fig. 8 Test samples - a) non-heat-treated, b) heat-treated Source: authors

listed in Tables 11 and 12. Difference in mean weight loss between samples was $0.0078 \mathrm{~g}$.

\section{Results and discussion}

One possibility to increase the wear resistance of the material is to change its structure by adequate heat treatment. $A$ more appropriate structure provides lower abrasive than in non-heat-treated tools per the same working time. During the experiment, according to the steel standard 14 220, we designed a thermal regime that ensured a change in material structure from ferritic-perlite to martensitic. According to literary sources, achieving the martensitic-carbide structure can result in a reduction in abrasive wear of the surfaces (Müller and Hrabě, 2013; Kováč and Tolnai, 2006). To confirm these assumptions, hardness tests, impact strength and wear resistance tests were performed. From their results it is clear that the samples after heat treatment have better resistance to abrasion (Tables 9 and 10, graph in Fig. 9). Although these values are not high, it is assumed that more favourable results could be achieved in further experiments, in which the material heat treatment parameters would vary. Notch hardness test on non-heat-treated and heat-treated samples showed an increase in the value of consumed work by 3.5 times in average. This is beneficial for the impact load of mulching tools. The strength of fracture toughness also increases the resistance to brittle fracture at impact load, which demonstrates the reasonableness of the heat treatment of the exposed functional parts of tool. Obtained hardness after heat treatment (it is 35HRC) is not as high as in e.g. material enhanced by the surface hardening (it is $60 \mathrm{HRC}$ ). However, we can say that using heat treatment on mulcher body tool can increase the lifetime of tool after losing the WC tips. Therefore, we would recommend changing the technology process of tool production: to make the heat treatment of body in the first step and to solder the WC tips on the body in the second step.

In addition to the overall degradation of the tool, working even despite the loss of the tip, it is necessary to take into account the behaviour of the whole system - rotating roller with unevenly worn tools becomes unbalanced, causing great vibrations and damaging the base machine's carrier. This ultimately affects the performance of the forestry tractor. Depending on the type, the price of one instrument varies between $€ 80-120$. When inserting about 48 tools (the quantity of tools is dependent on the roller length)

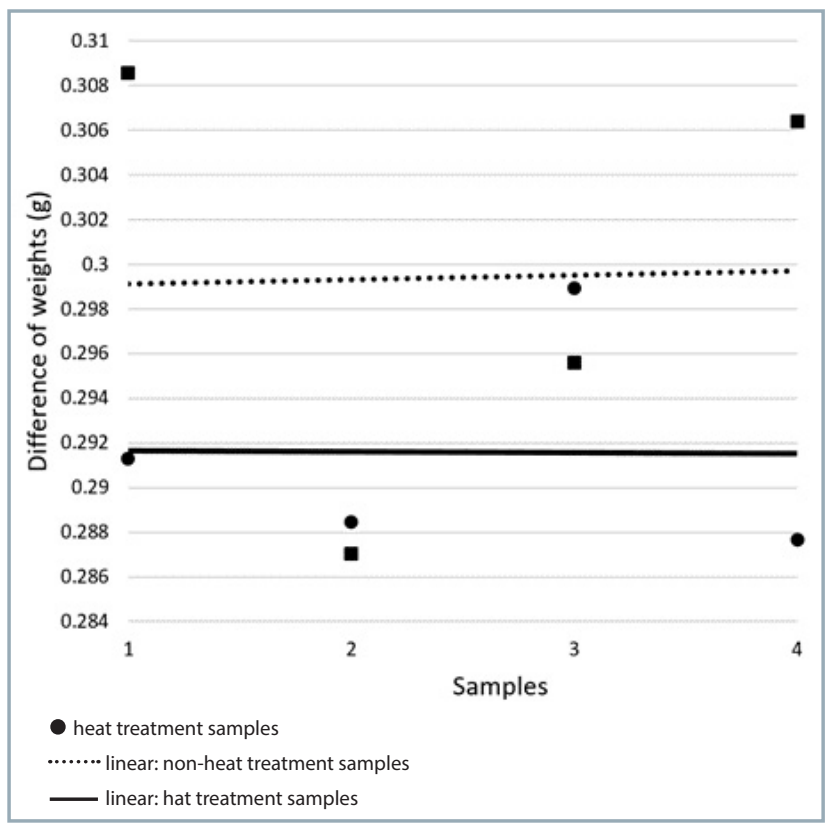

Fig. 9 Weight loss of samples - comparison 
on a rotating roller, this is not a negligible item. In addition to other things, tool wears down in a very short time and subsequently damages other machine nodes. This issue needs to be addressed in order to save the costs of tools and fuels, as well as to reduce the extra times required for frequent replacement of worn tools on the plant.

Currently, for the recovery of worn functional surfaces, production of surfaces with properties surpassing the properties of base material often applies different types of welds. Renovation as the technological process of rebuilding the shape and size of parts is becoming more and more popular, especially for economic reasons. An economically advantageous way of renovation is arc welding. Newly formed layers, surfaces of which form functional layers with a suitable combination of alloying elements and heat treatment, can exhibit significantly better properties than original respectively new components (Viňáš et al., 2011; Votava, 2014;). Therefore, it is interesting to perform experiments with mulching tools, on which the addition of suitable additives will be applied.

\section{Conclusion}

The work of mulching tools of forest-environment conditioning equipment is characterized by increased impact loads in inhomogeneous working environment. High rotor speed (800-1000 rpm) on which the tools are mounted, uneven load on the tools, as well as potential tool faults, contribute to their faster wear, affecting their durability and lifetime. Selecting appropriate adjustments on the tool's functional surfaces would result in longer durability and lifetime. Innovations in this area would also bring economic and environmental benefits.

\section{Acknowledgment}

The paper was developed as part of the APVV-16-0194 "Research on Impact of Innovation in Production Processes on the Life of Tooling and Components of Forest Mechanisms".

\section{References}

BLAŠKOVIČ, P. - BALLA, J. - DZIMKO, M. 1990. Tribology. Bratislava : Alfa. 360 pp. ISBN 80-05-00633-0.

BROŽEK, M. - NOVÁKOVÁ, A. 2008. Evaluation of sintered carbides wear resistance. Available online at: http://tf.llu.lv/conference/ proceedings2008/Papers/40_Brozek.pdf [viewed 14.3.2018]

BUCKLEY, D. H. 1981. Surface Effects in Adhesion, Friction, Wear and Lubrication. Tribology Series 5. Amsterdam-Oxford-New York : Elsevier Scientific Publishing Company. 631 pp.

ČSN 01 5084. 1974. Determination of metal material resistance against wear by abrasive cloth. ÚNM Praha.

Forestry Mulchers [online] [viewed 14.05.17]. Available: www.seppi. com/en/mulcher-mower-shredder-tiller-stump-grinder/forestrymulchers.html.
HDT Prinoth. Available online at: https://www.prinoth.com/en/ vegetation-management/products/teeth/hdt-176/ [viewed 14.5.2017]

HNILICA, R. - MESSINGEROVÁ, V. - STANOVSKÝ, M. 2015. Possibilities of mechanization of work on forest founding and education. (Scientific monography). 99 pp. ISBN 978-80-228-2722-5.

HNILICOVÁ, M. - HNILICA, R. - DADO, M. 2016. Technique and technology in the upbringing and cultivation of the forest. In Increasing the Life of Tools and Structural Parts of Mechanisms. Zvolen : Technická univerzita, 2016. pp. 16-26. ISBN 978-80-228-2862-8.

KALINCOVÁ, D. - ŤAVODOVÁ, M. 2016. Analysis of the mulcher tools wear - methods for increasing of wear resistance. In Increasing the Life of Tools and Structural Parts of Mechanisms. Zvolen : Technická univerzita, 2016, pp. 52-58. ISBN 978-80-228-2862-8.

KINGKONG-TOOLS. Available online at: www.kingkong-tools.com [viewed 14.5.2017]

KOVÁČ, I. - TOLNAI, R. 2006. Zlepšenie mechanických vlastností povrchových vrstiev ocelí 14220 a 15230 nasýtených bórom. In Acta Technologica Agriculturae, vol. 9, no. 1, pp. 1-3.

KRAUZE, K. - BOŁOZ, Ł. - WYDRO T. 2015. Parametric factors for the tangential-rotary picks quality assessment. In Archives of Mining Sciences, vol. 60, no. 1, pp. 265-281.

LUPTÁČIKOVÁ, V. 2016. Options rototillers categorized according to the use of working tools. In Colloquium to grant no. $1 / 0826 / 15$, scientific peer-reviewed collection, pp. $80-89$. ISBN 978-80-228-2920-5.

MÜLLER, M. - HRABĚ, P. 2013. Overlay materials used for increasing lifetime of machine parts working under conditions of intensive abrasion. In Research in Agricultural Engineering, vol. 59, no. 1, pp. 16-22.

STN 01 5084. 1974. Determination of metal material resistance against wear by abrasive cloth. SÚTN Bratislava.

STN 41 4220. 1976 Manganese-chromium steel 14 220. SÚTN Bratislava.

STN EN ISO 148-1. 2017 Metallic materials - Charpy pendulum impact test. Part 1: Test method. SÚTN Bratislava.

STN EN ISO 6507-1. 2006. Metallic materials. Vickers hardness test. Part 1: Test method. SÚTN Bratislava.

ŤAVODOVÁ M. - KALINCOVÁ, D. - HNILICOVÁ, M. - HNILICA, R. 2016. The influence of heat treatment on tool properties mulcher. In Manufacturing Technology, vol. 16, no. 5, pp. 1169-1173.

TOLNAI, R. - ČIČO, P. - KOVÁČ, I. 2006. Impact strength of steels as a criterion of material resistance. In Acta Technologica Agriculturae, vol. 9, no. 1, pp. 17-19.

VIŇÁŠ, J. - BREZINOVÁ, J. - GUZANOVÁ, A. - LORINCOVÁ, D. 2011. Properties of renovation layers applied by submerged arc welding. In Chemické Listy, vol. 105, no. 17, pp. 858-859.

VOTAVA, J. - ČERNÝ, M - FILÍPEK, J. 2005. Vliv tepelného zpracování na abrazivní opotřebení. In Acta Universitatis Agriculturae et Silviculturae Mendelianae Brunensis, vol. LIII, no. 5, pp. 175-185.

VOTAVA, J. 2014. Usage of abrasion-resistant materials in agriculture. In Journal of Central European Agriculture, vol. 15, no. 2, pp. 119-128. 